\title{
ВПЛИВ ПСИХОСОМАТИЧНИХ ФАКТОРІВ НА КЛІНІЧНІ ОСОБЛИВОСТІ КОМОРБІДНОГО ПЕРЕБІГУ ГІПЕРТОНІЧНОї ХВОРОБИ ТА ПРИХИЛЬНІСТЬ ДО АНТИГІПЕРТЕНЗИВНОӦ ТЕРАПІЇ У МІСЬКИХ І СІЛЬСЬКИХ ЖИТЕЛІВ
}

\author{
๑М. П. Черкун, І. П. Катеренчук \\ Українська медична стоматологічна академія, Полтава
}

РЕзЮМЕ. Мета - визначити значимість впливу психосоціальних факторів, а саме тривоги та депресії, на клінічний перебіг гіпертонічної хвороби в умовах коморбідності та прихильність до антигіпертензивної терапії у сільських та міських жителів.

Матеріал і методи. Обстежено та проаналізовано лікування 152 хворих на гіпертонічну хворобу, які перебували на стаціонарному лікуванні в Полтавському обласному медичному клінічному кардіоваскулярному центрі протягом 2018-2020 років. Пацієнти були поділені на групи залежно від ізольованого чи поєднаного перебігу гіпертонічної хвороби, а також від місця проживання, за віковими і ґендерними ознаками. Наявність тривоги та депресії визначали шляхом використання госпітальної шкали тривоги і депресії (HADS). Прихильність до антигіпертензивної терапії визначали за допомогою розширеного і модифікованого опитувальника Моріски-Грін.

Результати. Достовірно встановлено прямий кореляційний зв'язок $(p>0,05)$ між наявністю в однієї досліджуваної особи і тривоги і депресії та наявністю коморбідної патології і відсутність залежності від територіальної належності $(p<0,001)$ досліджуваних пацієнтів. Незалежно від територіальної належності жінки більше, ніж чоловіки, схильні до проявів тривоги або/і депресії, майже на 20,0\%. Зниження рівня прихильності мало зворотну кореляційну залежність зі зростанням коморбідної патології, наявністю та ступенем вираженості тривоги та/або депресії у порівнюваних групах.

Висновки. Ізольований перебіг гіпертонічної хвороби у меншій мірі поєднується з такими психосоціальними факторами як тривога та/або депресія, тоді як зі зростанням коморбідності у перебігу ГХ прослідковується прямий кореляційний зв'язок між зростанням тривожно-депресивної симптоматики та супутніми IXC та ЦД 2-го типу. У всіх досліджуваних групах виявлена більша схильність міських жителів до розвитку тривоги та депресії, порівняно з сільськими жителями. Низька прихильність до лікування асоціювалася зі зростанням коморбідної патології та наявністю клінічно вираженої тривоги та депресії.

КлючовІ СлОВА: гіпертонічна хвороба; тривога; депресія; психосоціальні фактори.

Вступ. На захворювання системи кровообігу припадає 35,6 \% у структурі смертності українців вікової групи до 65 років [1, 2]. До основних коригованих факторів ризику кардіоваскулярної патології (КВП) відносять наявність шкідливих звичок, надлишкової ваги тіла та/або ожиріння, низьку фізичну активність, нездорове харчування, психосоціальний стрес [1, 3-5].

За результатами стандартизованого дослідження INTERHEART, до якого було залучено 52 країни світу, доведено, що можливість виникнення інфаркту міокарда в осіб, які перебувають в умовах психосоціального стресу, в 2,67 раза вища, ніж у популяції $[1,6]$. Сучасними науковцями доведено, що основними психосоціальними факторами ризику КВП $\epsilon$ тривога, депресія та надмірний вплив стресу на індивіда в умовах нинішнього часу. Встановлена і наявність спільних ланок у патогенезі та фізіологічних механізмах розвитку депресії та КВП, а саме порушення регуляції на рівні гіпоталамо-гіпофізарно-адреналової, імунної, метаболічної систем. Перебування в умовах постійного стресу $\epsilon$ незалежним предиктором виникнення як серцево-судинних захворювань (ССЗ), так і депресії. Внаслідок даної дизрегуляції та дії стресу розвивається активація симпатичної нервової системи, що впливає на виникнення і прогресування гіпертонічної хвороби (ГХ) $[3,7]$. Достовірно підтвердженим $\epsilon$ факт зниження якості життя та підвищення рівня смертності від СС3, що відбувається саме в коморбідності з тривогою та депресією. Ці обставини дають підставу провідним науковцям відносити депресію до первинних факторів ризику розвитку ССЗ $[3,8,9]$.

Дані Всесвітньої організації охорони здоров'я (ВООЗ) свідчать про зростання депресивної симптоматики на 5,7 \%, яка вже у 2020 році може стати другою причиною інвалідизації населення світу після ішемічної хвороби серця (IXC) [7]. Згідно з даними статистики, близько $7 \%$ нашого населення мають депресію і не знають про це, депресія $\epsilon$ у 22-33 \% осіб із соматичною патологією і в близько половини пацієнтів, які перенесли інфаркт міокарда $[7,10]$. Депресія $€$ обтяжуючим фактором в діагностиці, клінічному перебігу та погіршує прогноз соматичної патології щодо отримання позитивного ефекту від лікування та одужання. Вплив на психічну складову психосоматичних хвороб, за даними різних авторів, може подовжити життя пацієнтів на 6-7 років $[3,7]$.

Тривога - ще одне з найпоширеніших психічних захворювань популяції всіх країн світу, що та- 
Огляди літератури, оригінальні дослідження, погляд на проблему, випадок з практики, короткі повідомлення кож обтяжує соматичну патологію та знижує якість життя пацієнтів [11, 12]. Також наявні дослідження, що підтверджують зв'язок тривоги з гіпертонічною хворобою. Встановлено, що особи з тривогою мають більший ризик виникнення і розвитку ГХ, ніж пацієнти без підтверджених ознак наявності тривоги, і навпаки, пацієнти з вже встановленим діагнозом ГХ більш схильні до виникнення тривожних розладів, ніж без гіпертензії $[11,13]$.

Мета - визначити значимість впливу психосоціальних факторів, а саме тривоги та депресії, на клінічний перебіг гіпертонічної хвороби в умовах коморбідності, а також прихильність до антигіпертензивної терапії у сільських та міських жителів.

Матеріал і методи дослідження. Обстежено та проаналізовано результати лікування 152 паці$\epsilon$ нтів, хворих на гіпертонічну хворобу, які перебували на стаціонарному лікуванні в Полтавському обласному медичному клінічному кардіоваскулярному центрі протягом 2018-2020 років.

Пацієнти були поділені на групи залежно від ізольованого чи поєднаного перебігу гіпертонічної хвороби та залежно від місця проживання. Характеристика пацієнтів залежно від супутньої коморбідної патології та територіальної належності наведена в таблиці 1.

Розподіл пацієнтів за віковими та гендерними ознаками наведено в таблиці 2.

Таблиця 1. Характеристика груп хворих залежно від коморбідного перебігу гіпертонічної хвороби та територіальної належності

\begin{tabular}{|c|c|c|c|}
\hline \multicolumn{2}{|r|}{ Групи хворих } & $\begin{array}{c}\text { Міські жителі } \\
\quad(n=84)\end{array}$ & $\begin{array}{c}\text { Сільські жителі } \\
(n=68)\end{array}$ \\
\hline I & ГХ (абс., \%) & $26(31,0)$ & $19(27,9)$ \\
\hline II & ГХ в поєднанні з ІХС (абс., \%) & $34(40,5)$ & $34(50,0)$ \\
\hline III & ГХ в поєднанні з ІХС та ЦД 2-го типу (абс., \%) & $24(28,5)$ & $15(22,1)$ \\
\hline
\end{tabular}

Таблиця 2. Характеристика груп хворих залежно від віку, статі та територіальної належності

\begin{tabular}{|l|c|c|c|c|c|c|}
\hline \multirow{2}{*}{ Ознака } & \multicolumn{4}{c|}{ Групи хворих } \\
\cline { 2 - 7 } & \multicolumn{2}{|c|}{ I (n=45) } & \multicolumn{2}{c|}{ II (n=68) } & \multicolumn{2}{c|}{ III (n=39) } \\
\hline Територіальна належність & $\begin{array}{c}\text { міські } \\
\text { жителі }\end{array}$ & $\begin{array}{c}\text { сільські } \\
\text { жителі }\end{array}$ & $\begin{array}{c}\text { міські } \\
\text { жителі }\end{array}$ & $\begin{array}{c}\text { сільські } \\
\text { жителі }\end{array}$ & $\begin{array}{c}\text { міські } \\
\text { жителі }\end{array}$ & $\begin{array}{c}\text { сільські } \\
\text { жителі }\end{array}$ \\
\hline Середній вік пацієнтів, років & $52,6 \pm 2,1$ & $47,9 \pm 2,8$ & $57,6 \pm 1,4$ & $58,0 \pm 1,7$ & $67,0 \pm 1,6$ & $65,3 \pm 1,9$ \\
\hline Пацієнти чоловічої статі (а6с., \%) & $18(69,2 \%)$ & $7(36,8 \%)$ & $11(32,4 \%)$ & $16(47,1 \%)$ & $11(45,8 \%)$ & $7(46,7 \%)$ \\
\hline Пацієнти жіночої статі (а6с., \%) & $8(30,8 \%)$ & $12(61,2 \%)$ & $23(67,6 \%)$ & $18(52,9 \%)$ & $13(54,2 \%)$ & $8(53,3 \%)$ \\
\hline
\end{tabular}

Групи були зіставні за віком, статтю, територіальною належністю та за перебігом гіпертонічної хвороби.

Наявність тривоги та депресії визначали шляхом використання госпітальної шкали тривоги і депресії (HADS) [7]. Ця шкала містить 7 запитань для визначення тривоги та 7 запитань для визначення депресії, кожному запитанню відповідає 4 варіанти відповіді з відповідною кількістю балів. Пацієнтів, які набрали від 0 до 7 балів, вважали такими, що не мають достовірно виражених симптомів тривоги та депресії. Наявність субклінічно вираженої тривоги та депресії підтверджувалась у пацієнтів, котрі набрали від 8 до 10 балів. Клінічно виражена тривога та депресія мала місце у пацієнтів, що набирали 11 і вище балів.

Прихильність до антигіпертензивної терапії визначали за допомогою розширеного і модифікованого опитувальника Моріски-Грін, що включав у себе 8 запитань (MMAS-8), за кожне з яких прихильний до лікування пацієнт міг отримати по 1 балу. Згідно з цим опитувальником, пацієнти мали високий, середній та низький рівні прихиль- ності. Пацієнти, які набрали 8 балів, мали високий рівень, 6-7 балів - середній рівень, менше 6 балів низький рівень прихильності [14]. Вплив тривоги та депресії на сільських та міських жителів, а також на прихильність до лікування, аналізували за допомогою статистичної обробки даних з використанням програми Microsoft Office Excel 2010 на базі MS Windows 10. Оцінку статистичної значущості результатів проводили за методом $\left(\chi^{2}\right)$ Пірсона.

Результати й обговорення. У групі з ізольованим перебігом гіпертонічної хвороби (контрольна група) не мали достовірно виражених симптомів тривоги та депресії 55,6 \% пацієнтів, тоді як 45,4 \% мали субклінічно чи клінічно виражені ознаки тривоги та/або депресії. При цьому жителі міста даної групи були більш схильні до субклінічно вираженої депресії у 15,4 \% випадків та клінічно вираженої тривоги у 7,7 \% випадків, ніж жителі сільської місцевості. Натомість у жителів сільської місцевості найчастіше виявляли прояви субклінічної тривоги (21,1\%).

У групі пацієнтів з коморбідним перебігом гіпертонічної хвороби та IXC відсутність достовірно 
Огляди літератури, оригінальні дослідження, погляд на проблему, випадок з практики, короткі повідомлення виражених симптомів тривоги та депресії констатували у 44,1% пацієнтів. Прояви депресії у цих пацієнтів майже не виявляли. Проте прояви тривоги були наявні у 26,5 \% пацієнтів сільської місцевості та у 32,3 \% міських мешканців. Субклінічно та клінічно виражені ознаки тривоги і депресії разом проявлялися частіше у жителів міста (20,6 \% проти 26,5\%).

У третій групі, з коморбідним перебігом гіпертонічної хвороби, IXC та цукрового діабету (ЦД)

2-го типу, ознак тривоги та депресії не спостерігали у 13,3 \% сільських пацієнтів та у 8,3 \% міських. Ізольовано субклінічних проявів депресії не спостерігали, тоді як клінічно депресія проявлялася у 2 (13,3\%) пацієнтів сільської місцевості та 2 (8,3 \%) міської місцевості. Прояви тривоги відмічали у 20,0 \% сільських жителів та 20,8 \% містян. Одночасно прояви депресії та тривоги визначалося у 8 (53,3 \%) сільських та 15 (62,5 \%) міських жителів (табл. 3).

Таблиця 3. Прояви тривоги та депресії у порівнюваних групах

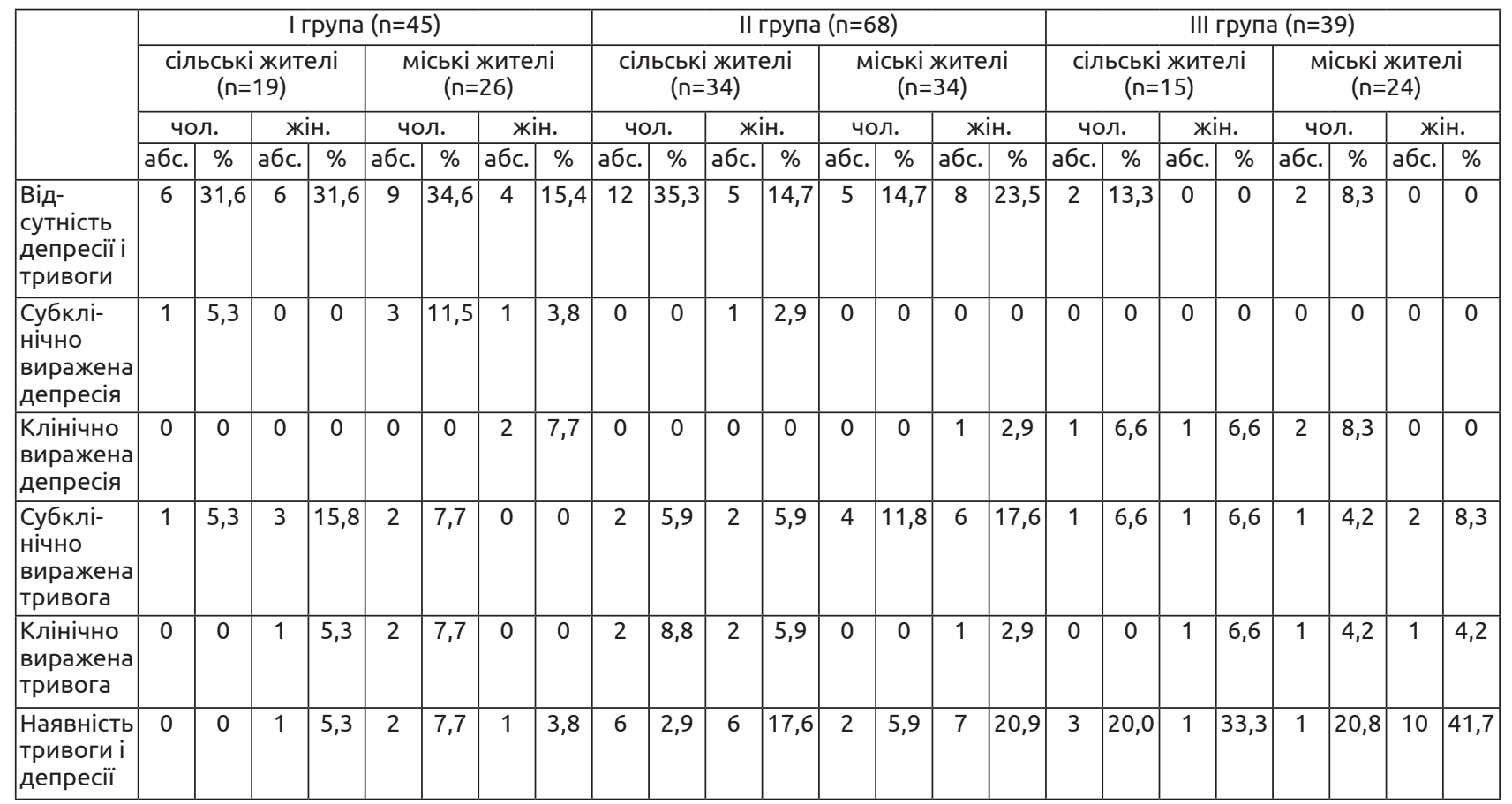

У групі хворих з коморбідним перебігом гіпертонічної хвороби, IXC та цукрового діабету (ЦД) 2-го типу встановлена достовірно більша кількість випадків субклінічно та/або клінічно вираженої тривоги і депресії, порівняно з досліджуваними попередніх двох груп - 91,7 \% у жителів міста та 86,7 \% - жителів сільської місцевості $(p>0,05)$.

Достовірно встановлено прямий кореляційний зв'язок $(p>0,05)$ між наявністю в однієї дослі- джуваної особи і тривоги, і депресії, та наявністю коморбідної патології, який не залежить від територіальної належності $(p<0,001)$ досліджуваних пацієнтів. Незалежно від територіальної належності жінки більше, ніж чоловіки, схильні до проявів тривоги або/і депресії, майже на 20,0 \%.

Прихильність до антигіпертензивної терапії, визначена у відсотковому співвідношенні по групах пацієнтів, представлена у таблиці 4. Зниження рівня прихильності мало зворотну кореляційну

Таблиця 4. Залежність прихильності до лікування від територіальної належності пацієнтів

\begin{tabular}{|l|c|c|c|c|c|c|}
\hline \multirow{2}{*}{$\begin{array}{l}\text { Рівень } \\
\text { прихильності }\end{array}$} & \multicolumn{4}{|c|}{ Групи порівняння } \\
\cline { 2 - 7 } & \multicolumn{2}{|c|}{ І } & \multicolumn{2}{|c|}{ II } & \multicolumn{2}{c|}{ III } \\
\cline { 2 - 7 } & міські жителі & сільські жителі & міські жителі & сільські жителі & міські жителі & сільські жителі \\
\hline $\begin{array}{l}\text { Високий } \\
\text { абс., \% }\end{array}$ & $3(11,5)$ & $2(10,5)$ & $6(17,6)$ & $5(14,7)$ & $2(8,3)$ & $1(6,7)$ \\
\hline $\begin{array}{l}\text { Середній } \\
\text { абс., \% }\end{array}$ & $6(23,1)$ & $6(31,6)$ & $9(26,5)$ & $8(23,5)$ & $3(12$, & $5(33,3)$ \\
\hline $\begin{array}{l}\text { Низький } \\
\text { абс., \% }\end{array}$ & $17(65,4)$ & $11(57,9)$ & $19(55,9)$ & $21(61,8)$ & $19(79,2)$ & $9(60,0)$ \\
\hline
\end{tabular}


Огляди літератури, оригінальні дослідження, погляд на залежність зі зростанням коморбідної патології та наявністю і вираженістю тривоги та/або депресії у порівнюваних групах.

Висновки. 1. Ізольований перебіг гіпертонічної хвороби у меншій мірі поєднується з такими психосоціальними факторами як тривога та/або депресія, тоді як зі зростанням коморбідності у перебігу ГХ прослідковується прямий кореляційний блему, випадок з практики, короткі повідомлення зв'язок між зростанням тривожно-депресивної симптоматики та супутніми IXC та ЦД 2-го типу.

2. У всіх досліджуваних групах виявлена більша схильність міських жителів до розвитку тривоги та депресії, порівняно з сільськими жителями.

3. Низька прихильність до лікування асоціювалася зі зростанням коморбідної патології та наявністю клінічно вираженої тривоги та депресії.

\section{ЛІТЕРАТУРА}

1. Mukharovska I. R. Role of stress risk in development and course of cerebrovascular pathology / I. R. Mukharovska, M. Markova, T. Yavorska // Psychosomatic Medicine and General Practice. - 2018. - No. 3. - P. 1-10.

2. Стан демографічної ситуації в Україні: проблеми та шляхи їх вирішення / Л. А. Чепелевська, Ю. Б. Ященко, Н. Ю. Кондратюк, О. А. Семенюк // Україна. Здоров'я нації. - 2012. - № 6 (3). - С. 251-255.

3. Черкун М. П. Коморбідний перебіг гіпертонічної хвороби та цукрового діабету 2-го типу в умовах впливу психосоматичних факторів / М. П. Черкун, І. П. Катеренчук // Кардиология: от науки к практике. - 2019. № 4 (38). - C. 18-29.

4. Sherashov V. S. Modern scientific ideas about the risk factors for the development of cardiovascular diseases / V. S. Sherashov, N. V. Sherashova // World Congress of Cardiology, Dubai, United Arab Emirates.

5. Медико-психологічні фактори в прогнозуванні серцево-судинного ризику / О. М. Біловол, М. С. Панченко, Н. В. Кіча, І. М. Кравченко // Український журнал екстремальної медицини ім. Г. О. Можаева. - 2016. - Т. 18, № 4. - C. 10-16.

6. An adaptation of the framingham coronary heart disease risk function to European Mediterranean areas / J. Marrugat, R. D'Agostino, L. Sullivan [et al.] // J. Epidemiol Community Health. - 2003. - No. 57 (8). - P. 634-638.

7. Корнацький В. М. Вплив психосоціальних чинників на стан здоров'я та якість життя населення / В. М. Корнацький, Л. О. Дяченко, В. М. Михальчук // Український кардіологічний журнал. - 2017. - № 2. - С. 106-113.

\section{REFERENCES}

1. Mukharovska, I. R., Markova, M., \& Yavorska, T. (2018). Role of stress risk in development and course of cerebrovascular pathology. Psychosomatic Medicine and General Practice, 3, 1-10.

2. Chepelevska, L.A., Yashhenko, Yu.B., Kondratyuk, N. Yu., Semenyuk, O.A. (2012). Stan demohrafichnoi sytuatsii v Ukraini: problemy ta shliakhy yikh vyrishennia [The state of the demographic situation in Ukraine: problems and ways to solve them]. Ukraina. Zdorovia natsii Ukraine. Health of Nation, 6 (3), 251-255 [in Ukrainian].

3. Cherkun, M.P., \& Katerenchuk, I.P. (2019). Komorbidnyi perebih hipertonichnoi khvoroby ta tsukrovoho diabetu 2-ho typu v umovakh vplyvu psykhosomatychnykh faktoriv [Comorbid course of hypertension and type 2 diabetes mellitus under the influence of psychosomatic fac-
8. Эмоциональная дизрегуляция как фактор психосоматических нарушений при депресии и кардиоваскулярной патологии / В. С. Собенников, Е. В. Винокуров, Л. В. Рычкова, В. В. Собенникова // Acta biomedica scientifica. - 2019. - № 4 (1). - C. 87-92. DOI: 10.29413/ABS.2019-4.1.13.

9. Social support, depression, and heart disease: a ten year literature review / C. Zarbo, G. M. Manzoni, G. Castelnuovo [et al.] // Front. Psychol. - 2013. - No. 4. - P. 384. DOI: $10.3389 /$ fpsyg.2013.00384.

10. The neural bases of emotion regulation: reappraisal and suppression of negative emotion / P. R. Goldin, K. McRae, W. Ramel, J. J. Gross // Biological psychiatry. 2008. - No. 63 (6). - P. 577-586.

11. Пастернак Н. І. Тривожні та депресивні розлади у хворих на артеріальну гіпертензію / Н. І. Пастернак, О. С. Юрценюк // Клінічна та експериментальна патологія. - 2016. - № 1(55). - Р. 201-205.

12. Mental illness surveillance among adults in the United States / W. C. Reeves, T. W. Strine, L. A. Pratt [et al.] // MMWR Surveillance Summaries, 2011. - No. 60 (Suppl. 3). - P. 1-29.

13. The impact of mood and anxiety disorders on incident hypertension at one year / S. L. Bacon, T. S. Campbell, A. Arsenault, K. L. Lavoie // International Journal of Hypertension. - 2014. DOI: 10.1155/2014/953094

14. Morisky D. E. Concurrent and predictive validity of a self-reported measure of medication adherence / D. E. Morisky, L. W. Green, D. M. Levine // Medical Care. - 1986. Vol. 24. - P. 67-73.

tors]. Kardiologiya: ot nauky k praktike - Cardiology: From Science to Practice, 4(38), 18-29 [in Ukrainian].

4. Sherashov, V.S., \& Sherashova, N.V. Modern scientific ideas about the risk factors for the development of cardiovascular diseases (based on the materials of the World Congress of Cardiology, Dubai, United Arab Emirates).

5. Bilovol, O.M., Panchenko, M.S., Kicha, N.V., Kravchenko, I.M. (2016). Medyko-psykholohichni faktory v prohnozuvanni sertsevo-sudynnoho ryzyku [Medical and psychological factors in predicting cardiovascular risk]. Ukrainskyi zhurnal ekstremalnoi medytsyny im. H. O. Mozhaieva H. O. Mozhaiev Ukrainian Journal of Experimental Medicine, 18 (4), 10-16 [in Ukrainian].

6. Marrugat, J., D’Agostino, R., \& Sullivan, L. (2003). An adaptation of the Framingham coronary heart disease risk 
Огляди літератури, оригінальні дослідження, погляд на проблему, випадок з практики, короткі повідомлення function to European Mediterranean areas. J. Epidemiol. Community Health, 57 (8), 634-638.

7. Kornatskyi, V.M., Dyachenko, L.O., \& Mykhalchuk, V.M. (2017). Vplyv psykhosotsialnykh chynnykiv na stan zdorovia ta yakist zhyttia naselennia [The impact of psychosocial factors on the health and quality of life of the population]. Ukrainskyi kardiolohichnyi zhurnal - Ukrainian Cardiology Journal, 2, 106-113 [in Ukrainian].

8. Sobennykov, V.S., Vynokurov, E.V., Rychkova, L.V., \& Sobennykova, V.V. (2019). Emotsyonalnaya dyzregulyatsiya kak faktor psykhosomaticheskykh narusheniy pry depresii i kardiovaskulyarnoy patologii [Emotional dysregulation as a factor in psychosomatic disorders in depression and cardiovascular disease]. Acta Biomedica Scientifica, 4 (1), 87-92. DOI: 10.29413/ABS.2019-4.1.13 [in Russian].

9. Compare, A., Zarbo, C., \& Manzoni, G.M. (2013). Social support, depression, and heart disease: a ten year literature review. Front Psychol., 4, 384. DOI: 10.3389/fpsyg.2013.00384.

10. Goldin, P.R., McRae, K., Ramel, W., \& Gross, J.J. (2008). The neural bases of emotion regulation: reappraisal and suppression of negative emotion. Biol. Psychiatr., 63 (6), 577-586. DOI: 10.1016/j.biopsych. 2007.05.031.

11. Pasternak, N.I., \& Yurtsenyuk, O.S. (2016). Tryvozhni ta depresyvni rozlady u khvorykh na arterialnu hipertenziiu (ohliad literatury) [Anxiety and depressive disorders in patients with hypertension]. Klinichna ta eksperymentalna patolohiia - Clinical and Experimental Pathology, 1 (55), 201-205 [in Ukrainian].

12. Reeves, W.C., Strine, T.W., \& Pratt, L.A. (2011). Mental illness surveillance among adults in the United States. MMWR Surveillance Summaries, 60 (3), 1-29.

13. Bacon, S.L., Campbell, T.S., Arsenault, A., \& Lavoie, K.L. (2014). The impact of mood and anxiety disorders on incident hypertension at one year. International Journal of Hypertension. DOI: 10.1155/2014/953094.

14. Morisky, D.E., Green, L.W., \& Levine, D.M. (1986). Concurrent and predictive validity of a self-reported measure of medication adherence. Medical Care, 24 (1), 67-74.

\title{
ВЛИЯНИЕ ПСИХОСОМАТИЧЕСКИХ ФАКТОРОВ НА КЛИНИЧЕСКИЕ ОСОБЕННОСТИ КОМОРБИДНОГО ТЕЧЕНИЯ ГИПЕРТОНИЧЕСКОЙ БОЛЕЗНИ И ПРИВЕРЖЕННОСТЬ К АНТИГИПЕРТЕНЗИВНОЙ ТЕРАПИИ ГОРОДСКИХ И СЕЛЬСКИХ ЖИТЕЛЕЙ
}

\author{
Украинская медицинская стоматологическая академия, Полтава
}

РЕЗЮМЕ. Цель - определить значимость влияния психосоциальных факторов, а именно тревоги и депрессии, на клиническое течение гипертонической болезни в условиях коморбидности и приверженность к антигипертензивной терапии у сельских и городских жителей.

Материал и методы. Обследовано и проанализировано лечение 152 больных гипертонической болезнью, которые находились на стационарном лечении в Полтавском областном медицинском клиническом кардиоваскулярном центре в период 2018-2020 годов. Пациенты были поделены на группы в зависимости от изолированного или сочетаного течения гипертонической болезни, а также от места проживания, по возрастным и гендерным признакам. Наличие тревоги и депрессии определяли путем использования госпитальной шкалы тревоги и депрессии (HADS). Склонность к антигипертензивной терапии определяли с помощью расширенного и модифицированного опросника Мориски-Грин.

Результаты. Достоверно установлена прямая корреляционная связь $(p>0,05)$ между наличием у одного исследуемого пациента и тревоги, и депрессии, с наличием коморбидной патологии, и отсутствие зависимости от территориальной принадлежности $(p<0,001)$ исследуемых пациентов. Независимо от территориальной принадлежности женщины больше склонны к проявлениям тревоги и/или депрессии почти на 20,0\%, по сравнению с мужчинами. Снижение уровня приверженности имело обратную корреляционную зависимость с ростом коморбидной патологии, наличием и степенью выраженности тревоги и/или депрессии в исследуемых группах.

Выводы. Изолированное течение гипертонической болезни в меньшей степени сочетается с такими психосоциальными факторами как тревога и/или депрессия, тогда как с ростом коморбидности в течении ГБ прослеживается прямая корреляционная связь между ростом тревожно-депрессивной симптоматики и сопутствующими ИБС и СД 2-го типа. Во всех исследуемых группах обнаружена большая склонность городских жителей к развитию тревоги и депрессии, по сравнению с сельскими. Низкая приверженность к лечению ассоциировалась с ростом коморбидной патологии и наличием клинически выраженной тревоги и депрессии.

кЛючЕВыЕ СЛОВА: гипертоническая болезнь; тревога; депрессия; психосоциальные факторы. 

HYPERTENSION AND ADHERENCE TO ANTIHYPERTENSIVE THERAPY IN URBAN AND RURAL RESIDENTS

\section{@M. P. Cherkun, I. P. Katerenchuk}

\section{Ukrainian Medical Stomatological Academy, Poltava}

SUMMARY. The aim - to determine the significance of the influence of psychosocial factors, namely anxiety and depression on the clinical course of hypertension in conditions of comorbidity and adherence to antihypertensive therapy in rural and urban residents.

Material and Methods. We examined and analyzed the treatment of 152 patients with hypertension who were on inpatient treatment at the Poltava Regional Medical Clinical Cardiovascular Center during 2018-2020. Patients were divided into groups depending on the isolated or combined course of hypertension, as well as on the place of residence, by age and gender. The presence of anxiety and depression was determined by using the hospital scale of anxiety and depression (HADS). Adherence to antihypertensive therapy were determined using the extended and modified the questionnaire Morisky-Green.

Results. A direct correlation was established $(p>0.05)$ between the presence of anxiety and depression in one study group and the presence of comorbid pathology and does not depend on the territorial affiliation $(p<0.001)$ of the studied patients. Based on gender characteristics, it was found that regardless of territorial affiliation, women are more likely than men to manifest anxiety or/and depression by almost $20.0 \%$. The decrease in the level of adherence had an inverse correlation with the growth of comorbid pathology and the presence and severity of anxiety and/or depression in the compared groups.

Conclusions. An isolated course of hypertension is less associated with psychosocial factors such as anxiety and/or depression, whereas with an increase in comorbidity during HD, there is a direct correlation between the growth of anxiety-depressive symptoms and concomitant CAD and type 2 diabetes. In all the studied groups, the tendency of urban residents to develop anxiety and depression in comparison with rural residents was revealed. Low adherence to treatment was associated with an increase in comorbid pathology and the presence of clinically expressed anxiety and depression.

KEY WORDS: hypertension disease; anxiety; depression; psychosocial factors. 